TECHNICAL SCIENCES AND TECHNOLOGIES

УДК 624057 (477.51)

DOI: $10.25140 / 2411-5363-2021-2(24)-235-243$

Володимир Іванишин, Віктор Бугай, Микола Корзаченко

\title{
ІНЖЕНЕРНО-ГЕОЛОГІЧНІ ВИШУКУВАННЯ ПІД БУДІВНИЦТВО БАГАТОПОВЕРХОВИХ БУДИНКІВ 1, 2 НА ВУЛ. ЖАБИНСЬКОГО, 2А В МІСТІ ЧЕРНІГОВІ
}

У статті проведено дослідження четвертинних відкладів на території Чернігова під будівництво багатоповерхових будинкі 1, 2 на вул. Жабинського, 2а. За геоморфологічними ознаками досліджена ділянка знаходиться на Чернігівсько-Городнянській моренно-зандровій рівнині, за технологічним районуванням - в північно-західній частині Дніпровсько-Донеиької западини, покрита товстим шаром осадових порід. Інженерно-геологічна будова ї̈ вивчена до глибини 20 м. В інженерно-геологічних розрізах виділено 16 інженерно-геологічних елементів та 13 верств. Розріз складений сучасними, верхньо- і середньочетвертинними відкладами. У встановлених геологічних умовах найдоцільніший пальовий фундамент.

Ключові слова: ділянка; трунти; вишукування; інженерно-геологічні елементи; верства; зондування; свердловина; вода. Рис.: 5. Табл.: 1. Бібл.: 10.

Актуальність теми дослідження. На ділянках, на яких проєктується будівництво будь-яких об'єктів, обов'язково повинні проводитися польові й лабораторні інженерногеологічні дослідження. Від їх результатів і висновків залежить стійкість і безпечність. Тому такі дослідження завжди актуальні.

Постановка проблеми. Детальне вивчення четвертинних відкладів на території Чернігова під будівництво багатоповерхових будинків 1, 2 на вул. Жабинського, 2а.

Аналіз останніх досліджень і публікацій. Опубліковані матеріали за результатами інженерно-геологічних вишукувань на цій ділянці відсутні. В архівах знаходиться «Техническое заключение об инженерно-геологических изысканиях для строительства 9 эт. жилого дома со встроенно-пристроенным магазином «Продтовары» и помещением домоуправления №10 ЮЗЖД по ул. Жабинского в г. Чернигове. УКРГИИНТИЗ, 1989 г.» [1]; «Техническое заключение об инженерно-геологических изысканиях для строительства 212 кв. жилого дома 1-3, 4-6, магазина «Продтовары» и теплопункта № 9 в г. Чернигове по ул. Жабинского. УКРГИИНТИЗ, 1990 г.» [2]; «Техническое заключение об инженерно-геологических изысканиях для строительства комплекса зданий таможни в г. Чернигове по ул. Жабинского. Черниговстройизыскания. 1993 г.» [3].

Після цих технічних висновків минуло двадцять років і виникла потреба детально дослідити конкретну ділянку. Такі вишукування були проведені у 2014 році. Результати їх викладаються у нашій статті.

Виділення недосліджених частин загальної проблеми. Невирішеною частиною проблеми була відсутність результатів детального вивчення розповсюдження четвертинних відкладів на досліджуваній ділянці, їх літологічного складу, глибини залягання порід і грунтових вод.

Постановка завдання. Цільовим завданням робіт було вивчення інженерно-геологічних умов ділянки під будівництво багатоповерхових житлових будинків.

Виклад основного матеріалу. Інженерно-геологічні вишукування на ділянці відведеній під будівництво багатоповерхових будинків 1, 2 на вул. Жабинського, 2а в місті Чернігові виконані товариством 3 обмеженою відповідальністю «Чернігівбудрозвідування» згідно з договором з товариством з обмеженою відповідальністю «Житлобудсервіс».

Цільовим призначенням виконаних робіт було вивчення інженерно-геологічних умов ділянки під будівництво десятиповерхових житлових будинків.

Склад, об'єми та методика виконаних робіт наведені в таблиці.

За геоморфологічними ознаками досліджена ділянка знаходиться на Чернігівсько-Городнянській моренно-зандровій рівнині. Рельєф іiі відносно рівнинний, має абсолютні відмітки поверхні землі +140,22 - +141,3 м.

(C) Іванишин В. А., Бугай В. Г., Корзаченко М. М., 2021 
Табличя - Склад, обсяги та методика робіт

\begin{tabular}{|c|c|c|c|c|}
\hline $\begin{array}{l}\text { № } \\
\text { П.І. }\end{array}$ & Види робіт & Од. вим. & Кількість шт./м.п. & Методика виконаних робіт \\
\hline \multicolumn{5}{|c|}{ Польові роботи } \\
\hline 1 & Буріння свердловин & шт./M & $3 / 60$ & $\begin{array}{c}\text { Спосіб буріння -механічний } \\
\text { та ударно-контактний }\end{array}$ \\
\hline 2 & Статичне зондування & шт. & $6 / 20$ & {$[4]$} \\
\hline 3 & $\begin{array}{l}\text { Відбирання проб непорушеної } \\
\text { структури }\end{array}$ & шт. & $1 / 5$ & [4] \\
\hline \multicolumn{5}{|c|}{ Лабораторні роботи } \\
\hline 1 & Природна вологість & зразки & 39 & [5] \\
\hline 2 & Консистенція & зразки & 72 & [5] \\
\hline 3 & Щільність & зразки & 2 & [6] \\
\hline 4 & Гранулометричний склад & зразки & 12 & [7] \\
\hline 5 & Опір зрізу & зразки & 12 & [7] \\
\hline 6 & Компресійні випробування & проби & 3 & [8] \\
\hline
\end{tabular}

До і під час вишукувань вона була вільна від забудови. Північна межа ділянки підсипана на висоту 1,5-2,0 м, а в південній частині прорита канава для скидання поверхневих вод.

За тектонічним районуванням ділянка знаходиться в північно-західній частині Дніпровсько-Донецької западини, покрита товстим шаром осадових порід.

Інженерно-геологічна будова її вивчена до глибини 20 м. Вона грунтується на на розрізах I-I' і II-II' (рис. 1, 2) представлених інженерно-геологічними елементами 1-14 (рис. 3), які виділені за результатами буріння свердловин з врахуванням даних лабораторних досліджень (рис. 4), статичного зондування (рис. 5) та вишукувань минулих років. Розкриті породи залягають похило-горизонтально.

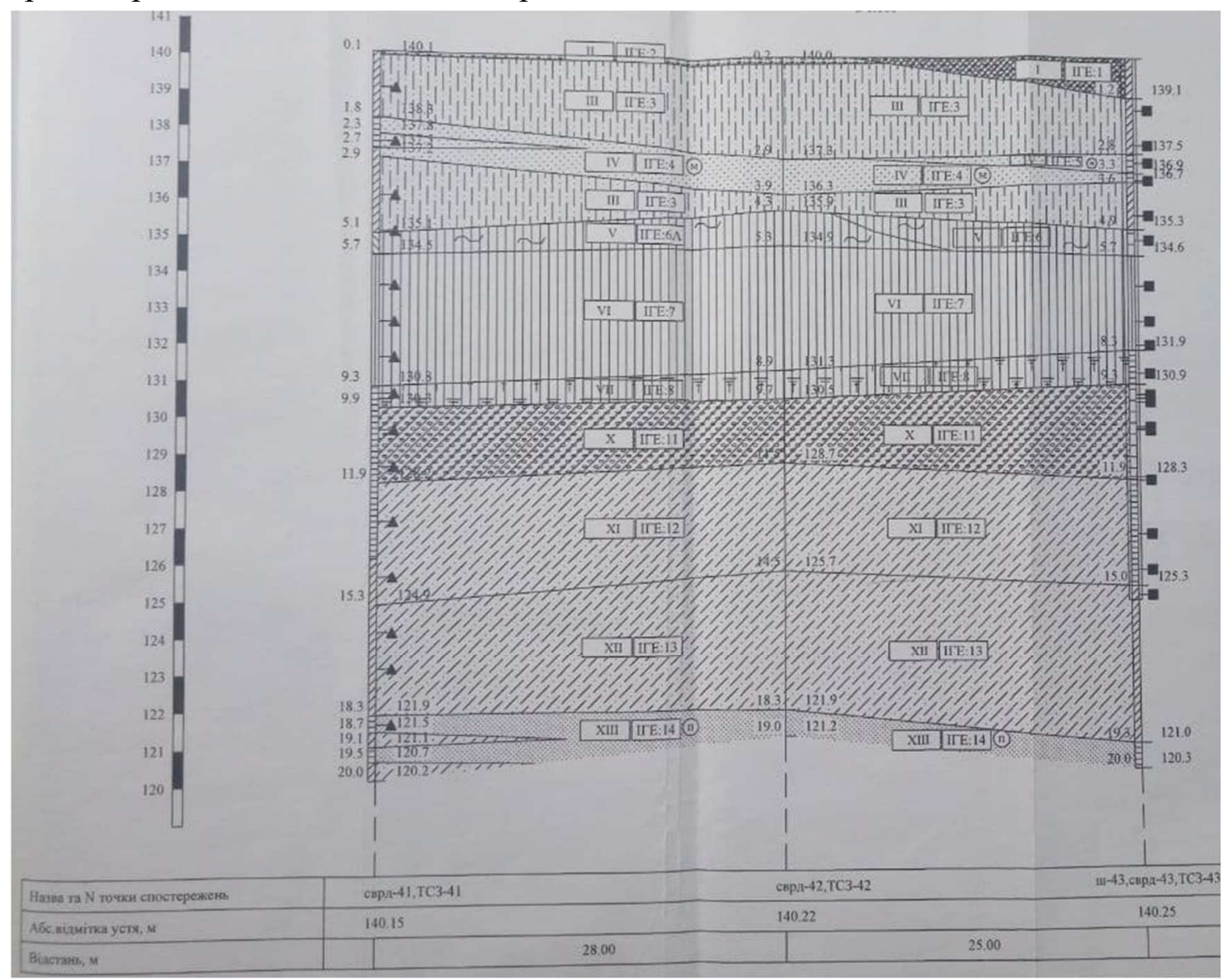

Рис. 1. Геологічний розріз I-I 


\section{TECHNICAL SCIENCES AND TECHNOLOGIES}

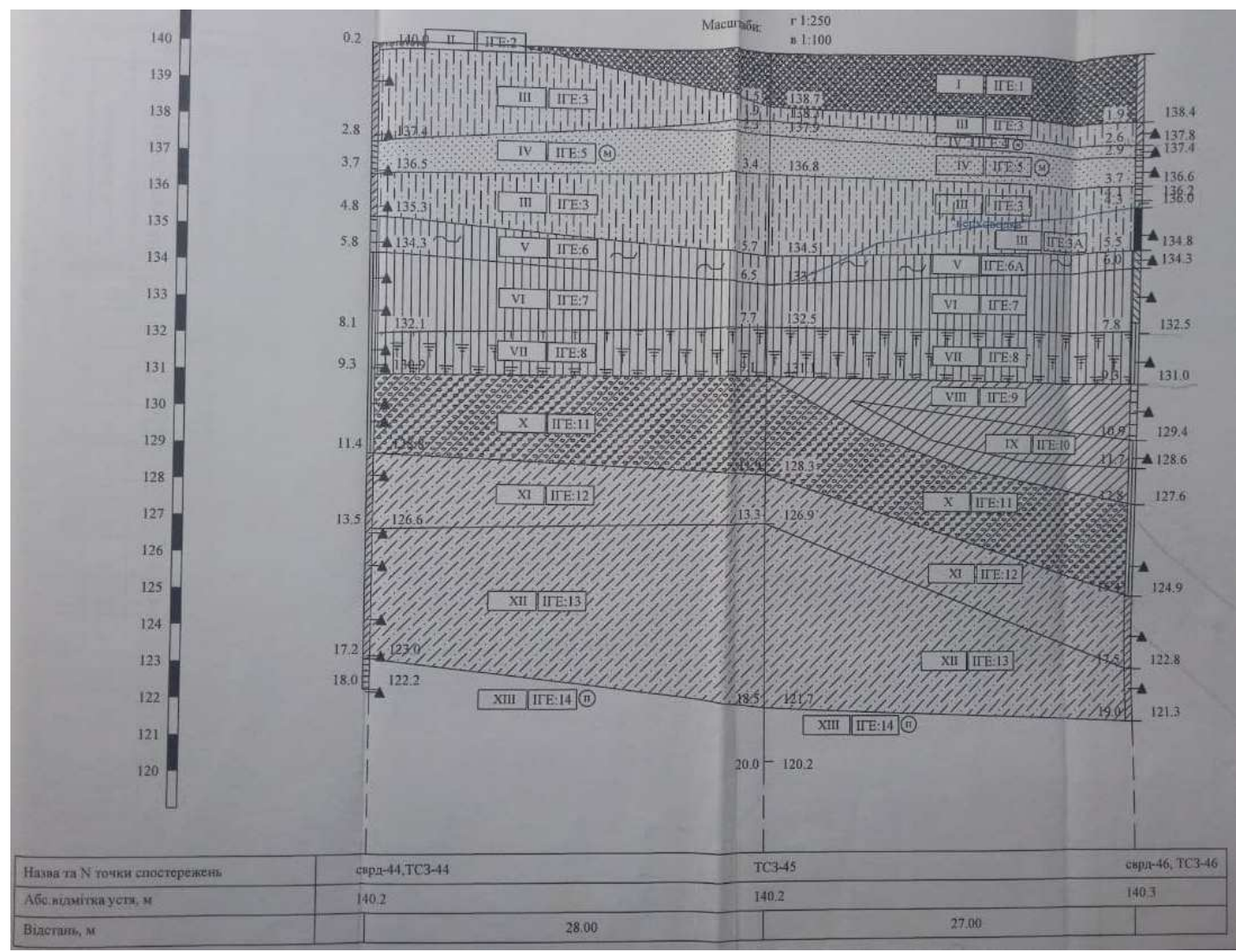

Рис. 2. Геологічний розріз II-II

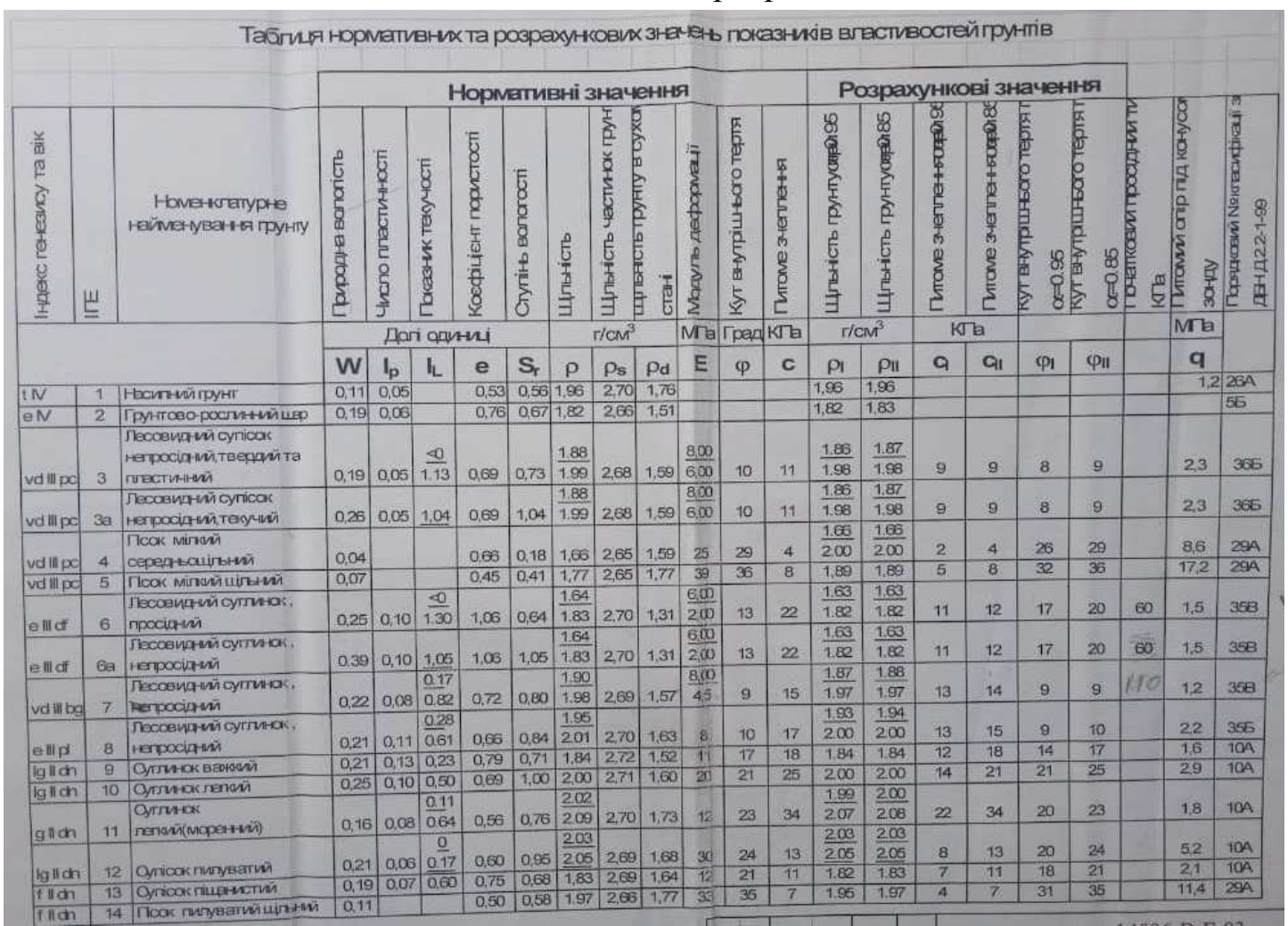

Рис. 3. Зведена інженерно-геологічна колонка з таблицею нормативних та розрахункових значень показників властивостей грунтів 


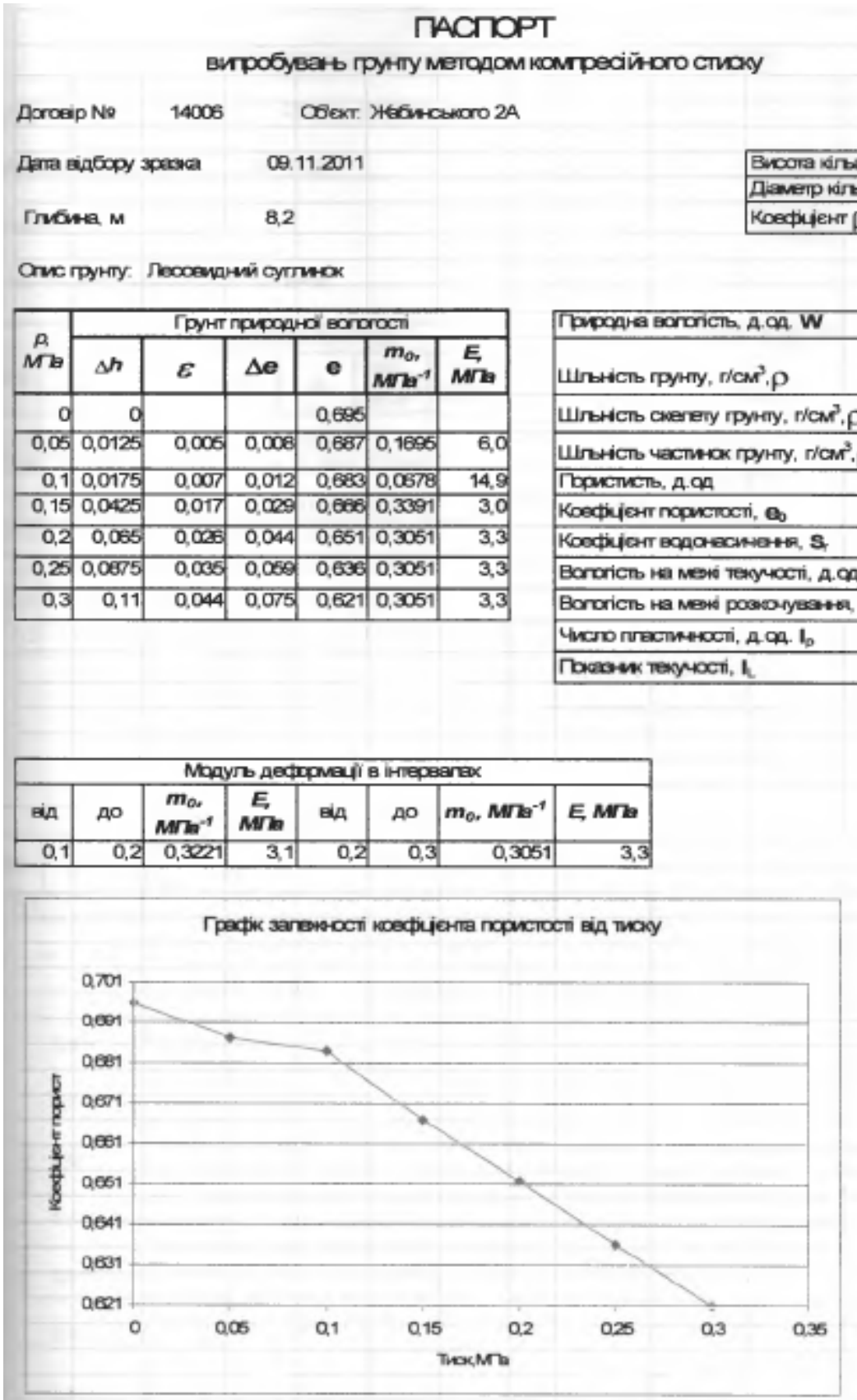

Рис. 4. Приклад паспорту лабораторних досліджень - випробування трунту методом компресійного стиску

У розрізах свердловини і на діаграмах статичного зондування до розвіданої глибини беруть участь верхньочетвертинні елювіальні (eIII), еолово-делювіальні (vdIII) та середньочетвертинні озерно-льодовикові (lgII), моренні (gII), флювіогляціальні (fII) відклади, покриті сучасними відкладеннями - грунтово-рослинним шаром (eIV) та насипними грунтами (tIV). Грунти залягають похило-горизонтально. Іноді серед них трапляються лінзи.

В інженерно-геологічних розрізах свердловин виділено 16 інженерно-геологічних елементів (IГЕ) та 13 верст (рис. 1, 2). Вони мають таку літологічну характеристику та відносний вік.

\section{Сучасні відкладення:}

Верства I - (IГE 1). Насипний грунт (tIV). Товщина до 1,9 м.

Верства II - (IГЕ 2). Грунтово-рослинний шар (eIV). Товщина 0,1-0,2 м. 
TECHNICAL SCIENCES AND TECHNOLOGIES

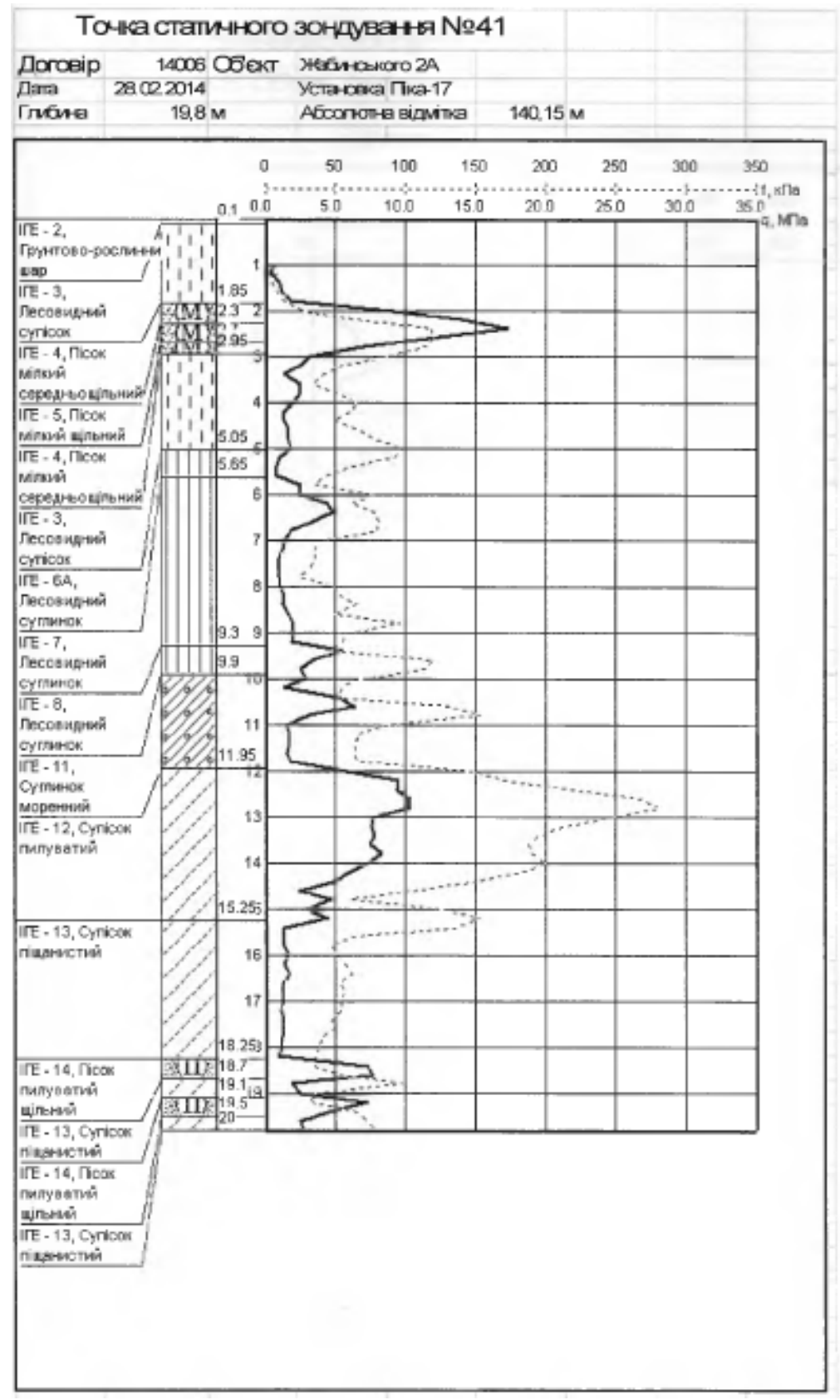

Рис. 5. Приклад графіка статичного зондування

Верхньочетвертинні еоло-делювіальні відклади причорноморського горизонту - vdIIIpc.

Верства III - (IГЕ 3). Супісок лесоподібний, непросідний, текучий, жовто-сірий, товщиною $0,4-2,7$ м.

IГЕ За. Супісок лесоподібний, непросідний, текучий, жовто-сірий, товщиною до 1,2 м.

Верства IV - (IГЕ 4). Пісок дрібнозернистий, середньо-щільний, жовто-сірий, товщиною до $1 \mathrm{M}$.

ІГЕ 5. Пісок дрібнозернистий, щільний, жовто-сірий, товщиною до 1,1 м.

Верхньочетвертинні еолові відклади дафінівського горизонту - eIIIdf.

Верства V - (IГЕ 6). Суглинок легкий, напівтвердий, сіро-коричневий, гумусований, товщиною 0,4-1,0 м.

IГЕ 6а. суглинок легкий, м'якопластиний та текучопластичний, сіро-коричневий, гумусований, товщиною 0,5-1,0 м. 
Верхньочетвертинні еоло-делювіальні відклади бузького горизонту - vdIIIbg.

Верства VI - (IГЕ 7). Суглинок легкий, м'якопластичний та тугопластичний, лесоподібний, жовто-сірий та ясно-сірий, товщиною 1,2-3,6 м.

Верхньочетвертинні еолові відклади прилуцького горизонту - eIIIpl.

Верства VII - (IГЕ 8). Суглинок легкий, м'якопластичний та тугопластичний, пилуватий, лесоподібний, сіро-коричневий та зеленувато-сірий, гумусований, товщиною 0,6-1,5 м.

Середньочетвертинні надморенні озерно-льодовикові відклади дніпровського віку lgIIdn.

Верства VIII - (IГЕ 9). Суглинок важкий, напівтвердий та тугопластичний, жовтосірий та ясно-сірий, товщиною 1,0-1,6 м (лише у розрізі свердловини 46).

Верства IX - (IГЕ 10). Суглинок легкий, тугопластичний, жовто-сірий та ясно-сірий, товщиною до 0,8 м (лише у розрізі свердловини 46 ).

Середньочетвертинні моренні відклади дніпровського віку gIIdn.

Верства X - (IГЕ 11). Суглинок морений, піщанистий, тугопластичний, жовто-сірий та жовто-бурий, з гравієм кристалічних порід до 2\%, товщиною 1,8-2,8 м.

Середньочетвертинні підморенні озерно-льодовикові відклади дніпровського віку - lgIIdn.

Верства XI - (IГЕ 12). Супісок пилуватий, пластичний, жовто-сірий та оранжево-сірий, товщиною 1,4-3,4 м.

Середньочетвертинні флювіогляціальні відклади дніпровського віку - fIIdn.

Верства XII - (IГЕ 13). Супісок піщанистий, пластичний, жовто-сірий та жовто-бурий, товщиною $1,5-5,2 \mathrm{M}$.

Верства XIII - (IГЕ 14). Пісок пилуватий, маловологий, жовто-сірий, товщиною до 0,7-1,5 м.

Результати розчленування геологічного розрізу дослідженої ділянки відображені на діаграмах статичного зондування, літологічних колонках свердловин та на інженерногеологічних розрізах (рис. 1-6).

Фізичні властивості грунтів у лабораторії вивчалися на монолітах та пробах порушеної структури, у польових умовах методом статичного зондування.

Виділення інженерно-геологічних елементів (ІГЕ) проведено згідно [9] та перевірено через аналіз просторової зміни природної вологості, меж пластичності та числа пластичності, коефіцієнтів щільності, механічних властивостей.

Товща грунтів до глибини 15-20 метрів розчленована на 16 інженерно-геологічних елементів, що значно перевищує активну зону взаємодії фундаментів будівель з їх основами.

Виділені інженерно-геологічні елементи не відповідають геолого-літологічним верствам відкладень.

Грунтові води на ділянці залягають глибоко. На початку квітня 2012 року їх рівень досягав близько 25 м, але при цьому можливе формування тимчасових горизонтів води - «верховодки».

Фізико-механічні властивості грунтів визначалися з врахуванням можливих (таких для яких є дані для прогнозування) змін геологічного середовища. Такі зміни можуть відбуватися при подальшому освоєнні ділянки, збільшенні техногенного навантаження на середовище.

Висновки.

1. Згідно з класифікацією ДБН А.2.1-1-2008 [10] за складністю інженерно-геологічних умов ділянка вишукувань віднесена:

- за геоморфологічними ознаками до I категорії;

- за геологічною будовою до III категорії;

- за гідрогеологічними умовами до I категорії;

- за наявністю специфічних грунтів до II категорії;

- за наявністю фізико-геологічних процесів до II категорії. 
TECHNICAL SCIENCES AND TECHNOLOGIES

Загалом досліджена ділянка відноситься до II категорії складності (ДБН В.2.1-10).

Розкрита товща грунтів (основа будівель, що проектувалися) неоднорідна.

Грунти IГЕ 3, 6а-8, які представлені лесовими супісками і суглинками, і періодично знаходилися в замоченому стані, не є просідними. Лесові грунти ІГЕ-6 - просідні. Сумарне просідання грунтів від власної ваги при замочуванні становило близько 3,4 см.

У встановлених геологічних умовах найдоцільніший пальовий фундамент.

Через те, що вивчена ділянка $\epsilon$ акумулятором поверхневих стічних вод, через завищення порога водостічної труби в районі Вокзальної площі, при ії забудові рекомендувалося облаштувати транзитне проходження стоків.

У випадку зміни габаритів будівлі у плані або зміни ії технічних характеристик зміст інженерно-геологічних висновків повинен бути уточнений у відповідності зі зміною умов будівництва.

Через можливість виникнення «верховодки» потрібні заходи передбачені ДБН В.1.1-5, зокрема забезпечити надійну ізоляцію водонесучих комунікацій та передбачити відведення атмосферних опадів 3 даху будівель, тротуарів, заасфальтованих площадок за межі об'єкта.

\section{Список використаних джерел}

1. Техническое заключение об инженерно-геологических изысканиях для строительства 9 эт. жилого дома со встроенно-пристроенным магазином «Продтовары» и помещением домоуправления №10 ЮЗЖД по ул. Жабинского в г. Чернигове. УКРГИИНТИЗ, 1989.

2. Техническое заключение об инженерно-геологических изысканиях для строительства 212 кв. жилого дома 1-3, 4-6, магазина «Продтовары» и теплопункта №9 в г. Чернигове по ул. Жабинского. УКРГИИНТИЗ, 1990.

3. Техническое заключение об инженерно-геологических изысканиях для строительства комплекса зданий таможни в г. Чернигове по ул. Жабинского. Черниговстройизыскания, 1993.

4. ДСТУ Б В.2-1-9-2002 Грунти. Методи польових випробувань статичним і динамічним зондуванням. [Чинний від 2001-05-30]. Київ : Держбуд, 2002. 24 с. (Державний стандарт України).

5. ДСТУ Б В.2.1-21-2009 Основи та підвалини будинків і споруд. Грунти. Визначення щільності грунтів методом заміщення об'єму. [Чинний від 2010-10-01]. Київ : Мінрегіонбуд України, 2009. 12 с. (Державний стандарт України).

6. ДСТУ Б В.2.1-3-96 Основи та підвалини будинків і споруд. Грунти. Лабораторні випробування. Загальні положення. [Чинний від 1997-01-01]. Київ : Держкоммістобудування, 1997. 34 с. (Державний стандарт України).

7. ДСТУ Б В.2.1-4-96 Основи та підвалини будинків і споруд. Грунти. Методи лабораторного визначення характеристик міцності і деформованості. [Чинний від 1997-04-01]. Київ : Держкоммістобудування, 1997. 107 с. (Державний стандарт України).

8. ДСТУ ISO 5667-11:2005 Якість води. Відбирання проб. Частина 11. Настанови щодо відбирання проб підземних вод. [Чинний від 2006-07-01]. Київ : Мінрегіонбуд України, 2006. 16 с. (Державний стандарт України).

9. ДСТУ Б В.2.1-5-96 Основи та підвалини будинків і споруд. Грунти. Методи статистичної обробки результатів випробувань. [Чинний від 1997-04-01]. Київ : Держкоммістобудування, 1997. 24 с. (Державний стандарт України).

10. ДБН А.2.1-1-2008. Вишукування, проектування і територіальна діяльність. Вишукування. Інженерні вишукування для будівництва. [Чинний від 2008-07-01]. Київ : Мінрегіонбуд України, 2008. 72 с. (Державні будівельні норми України).

\section{References}

1. UKRGIINTIZ (1989). Tehnicheskoe zakliuchenie ob inzhenerno-geologicheskikh izyskaniiakh dlia stroitelstva 9 et. zhilogo doma so vstroenno-pristroennym magazinom «Prodtovary» i pomescheniem domoupravleniia № $10 \mathrm{YuZZhD}$ po ul. Zhabinskogo v g. Chernigove [Technical conclusion on engineering and geological surveys for the construction of the 9th floor. a residential building with a built-in and attached store "Foodstuffs" and a building management room № 10 SouthWest Railway on the street Zhabinsky in the city of Chernigov]. 
2. UKRGIINTIZ (1990). Tehnicheskoe zakliuchenie ob inzhenerno-geologicheskikh izyskaniiakh dlia stroitelstva $212 \mathrm{kv}$. zhilogo doma 1-3, 4-6, magazina «Prodtovary» i teplopunkta № $9 \mathrm{v}$ g. Chernigove po ul. Zhabinskogo [Technical conclusion on engineering and geological surveys for the construction of 212 sq. M. dwelling house 1-3, 4-6, foodstuff store and heating point №. 9 in Almaty. Chernigov on the street Zhabinsky].

3. Chernigovstroyizyiskaniya (1993). Tehnicheskoe zakliuchenie ob inzhenerno-geologicheskikh izyskaniiakh dlia stroitelstva kompleksa zdanii tamozhni v g. Chernigove po ul. Zhabinskogo [Technical conclusion on engineering and geological surveys for the construction of a complex of customs buildings in Almaty. Chernigov on the street Zhabinsky].

4. Derzhbud (2002). Grunty. Metody polovykh vyprobuvan statychnym i dynamichnym zonduvanniam [Soils. Methods of field tests by static and dynamic sounding (DSTU B V.2-1-9-2002).

5. Ministry of Regional Development of Ukraine (2009). Osnovy ta pidvalyny budynkiv i sporud. Grunty. Vyznachennia shchilnosti hruntiv metodom zamishchennia obiemu [Foundations and foundations of buildings and structures. Soils. Determination of soil density by volume substitution] (DSTU B B.2.1-212009).

6. Derzhkommistobuduvannia (1997). Osnovy ta pidvalyny budynkiv i sporud. Grunty. Laboratorni vyprobuvannia. Zahalni polozhennia [Foundations and foundations of buildings and structures. Soils. Laboratory tests. General provisions] (DSTU B B.2.1-3-96).

7. Derzhkommistobuduvannia (1997). Osnovy ta pidvalyny budynkiv i sporud. Grunty. Metody laboratornoho vyznachennia kharakterystyk mitsnosti i deformovanosti [Foundations and foundations of buildings and structures. Soils. Methods of laboratory determination of strength and deformation characteristics] (DSTU B B.2.1-4-96).

8. Ministry of Regional Development of Ukraine (2006). Yakist vody. Vidbyrannia prob. Chastyna 11. Nastanovy shchodo vidbyrannia prob pidzemnykh vod [Water quality. Sampling. Part 11. Guidelines for groundwater sampling] (DSTU ISO 5667-11:2005).

9. Osnovy ta pidvalyny budynkiv i sporud. Hrunty. Metody statystychnoi obrobky rezultativ vyprobuvan [Foundations and foundations of buildings and structures. Soils. Methods of statistical processing of test results] (DSTU B. V. 2.1-5-96). (1997).

10. Minregionstroy of Ukraine (2008). Vyshukuvannia, proektuvannia i terytorialna diialnist. Vyshukuvannia. Inzhenerni vyshukuvannia dlia budivnytstva [Surveying, designing and territorial activity. Refinement. Engineering research for construction] (DBN A.2.1-1-2008).

UDC 624057 (477.51)

\section{Ivanyshyn Volodymyr, Buhay Viktor, Korzachenko Mykola}

\section{ENGINEERING AND GEOPHYSICAL SURVEYS FOR THE CONSTRUCTION OF THE HIGH-RISE APARTMENT BUILDINGS 1, 2 ON ZHABINSKY STREET $2 A$ IN CHERNIHIV}

On the sections where the construction of any objects are being designed, both field and laboratory exploratory surveys must be studied. Stability and safety depend on their results and conclusions. For this reason, such studies are always relevant.

The detailed study of the quaternary deposits on the territory of Chernihiv for the construction of the high-rise apartment buildings 1, 2 on Zhabinsky street 2 a.

There are no published materials about the results of engineering and geological surveys on this section. There are "The technical opinion concerning the engineering and geological surveys for the construction of the 9th floor of an apartment building with the built in-attached a "convenience" store and the house management placement №10 of the South-west railway station on Zhabinsky Street in Chernihiv. The Ukrainian state university of engineering research, 1989"; "The technical opinion concerning the engineering and geological surveys for the construction of $212 \mathrm{sq}$. $\mathrm{m}$. the apartment buildings 1-3, 4-6, a "convenience" store and heat exchangers №9 in Chernihiv on Zhabinsky Street, The Ukrainian state university of engineering research, 1990"; "The technical opinion concerning the engineering and geological surveys for the construction a complex of buildings custom house in Chernihiv on Zhabinsky Street. Chernihiv construction surveys, 1993" in the archives.

Twenty years have passed after these technical opinions and there was a need to study a particular section in detail. Such surveys have been conducted in 2014. The paper presents findings of a study on this issue.

The unsolved part of the problem was the absence of results for more detailed study of the spreading of quaternary sediments in the study area, their lithology, the depth of bedding of rocks and groundwater.

The purpose of the article was to study the engineering and geological conditions of the section for the construction of a high-rise apartment buildings. 


\section{TECHNICAL SCIENCES AND TECHNOLOGIES}

According to the geomorphological grounds, the section is located on the Chernihiv-Gorodnyansk moraine-outwash plain, through the technological regionalisation - to the north-western part of the Dniprovsko-Donetska cavity, covered with a thick layer of sedimentary rocks. The engineering and geological buildings have been studied to a depth of $20 \mathrm{~m}$. In the engineering and geological sections both 16 engineering and geological elements and 13 layers are identified. The section is composed by the modern, upper and medium sized quaternary sediments. The ground water lies at a depth about of 25 metres.

The studied area is generally applied to the II category of complexity.

The revealed thickness of the soil (the foundation of the designed buildings) is heterogeneous. The soils of EGE (engineering geological element) 3, 6a-8, which are represented by the loess sandy loam and the loams, and periodically were soaked in water, are non-sedimentary. The loess soils of EGE-6 are sedimentary.

Because of the possibility of "upgrade water", it is necessary to ensure reliable isolation of the water-carrying communications and foresee the withdraw of atmospheric precipitations from the roofs of buildings, the sidewalks and the asphalt grounds. The pile foundation is the most appropriate in the established geological conditions.

Keywords: area (section); soils; surveys; engineering and geological elements; layers; sounding; the well; water.

Fig.: 5. Table: 1. References 10.

І Іванишин Володимир Андрійович - доктор геологічних наук, професор, професор кафедри геодезії, картографії та землеустрою, Національний університет «Чернігівська політехніка» (вул. Шевченка, 95, м. Чернігів, 14035, Україна).

Ivanyshyn Volodymyr - Doctor of Geological Sciences, Professor, Professor of the Department of Geodesy, Cartography and Land Management, Chernihiv Polytechnic National University (95 Shevchenka Str., 14035 Chernihiv, Ukraine).

E-mail: gkz.kaf@gmail.com

ORCID: https://orcid.org/0000-0002-2394-1837

Бугай Віктор Григорович - начальник відділу, ТОВ «Чернігівбудрозвідування» (просп. Миру, 233а, м. Чернігів, 14006, Україна).

Buhay Viktor - Head of Department, Ltd. «Chernihivbudrozviduvannya» (223a Myru Av., 14006 Chernihiv, Ukraine). E-mail: 691040@ukr.net

Корзаченко Микола Миколайович - кандидат технічних наук, доцент кафедри технологій зварювання та будівництва, Національний університет «Чернігівська політехніка» (вул. Шевченка, 95, м. Чернігів, 14035, Україна)

Korzachenko Mykola - PhD in Technical Sciences, Associate Professor of the Department of Welding and Construction Technologies, Chernihiv Polytechnic National University (95 Shevchenka Str., 14035 Chernihiv, Ukraine).

E-mail: korzachenko_87@meta.ua

Researcher ID: F-5177-2016

ORCID: https:// orcid.org/0000-0002-5674-8662 